Promotion

\title{
POP goes the power wall? Taking aim at tobacco promotional strategies utilised at retail
}

\section{T Dewhirst}

\section{Tobacco promotion at the retail level is pervasive}

Ti obacco firms face an increasingly stringent regulatory environment. Despite having fewer viable options in the promotional mix, industry promotional spending has persisted, reaching record levels. In the USA, \$11.22 billion was spent on tobacco promotion during 2001. ${ }^{1}$ Once one form of promotion is banned, tobacco firms utilise other marketing strategies to continue communicating brand imagery. Radio and television advertising was no longer acceptable for cigarettes in New Zealand, the UK, the USA, Canada, and Australia, commencing in 1963, 1965, 1971, 1972, and 1976, respectively. Consequently, the tobacco industry shifted their promotional spending largely toward the print media. Individual tobacco companies also turned to sponsoring broadcast sports events to compensate for lost broadcast advertising exposure. In Canada, with the implementation of the Tobacco Products Control Act that stipulated a ban on tobacco product advertising, expenditures on sponsorship increased considerably during the late 1980s and early 1990s. ${ }^{2}$ And once bans were placed on tobacco sponsorship in countries such as Australia, Canada, and New Zealand, the tobacco industry placed further resources toward point-of-sale strategies, package design, trademark diversification, direct marketing campaigns, and "cigarette girls" who returned to bars and nightclubs. ${ }^{3-9}$ In the USA, a ban on billboard advertising, in accordance with the 1998 Master Settlement Agreement, prompted an increase in the prevalence of both interior and exterior tobacco advertising at retail outlets (fig 1). ${ }^{11}{ }^{11}$ Richard Pollay has remarked, "It's like squeezing a balloon. You can shut down one media, but the problem just moves somewhere else ${ }^{\prime \prime}{ }^{12}$

In the context of partial advertising bans, retail promotion, which consists of point-of-sale (POS) or point-of-purchase (POP) advertising, has become a central focus of tobacco marketing efforts. According to US advertising trade press, retail merchandising contracts are now the most potent part of a tobacco company's marketing arsenal, and "the contracts are cigarette marketers' primary marketing tool since the 1998 Master Settlement Agreement prohibited most tobacco advertising". ${ }^{13}$ A mere $2 \%$ of US tobacco advertising budgets was dedicated toward magazines, newspapers, and outdoor locations in 2001. ${ }^{1}$ Yet, when combining the point-of-sale advertising, promotional allowances (payments to retailers for shelf space), and retail value added (costs associated with bonus items distributed at retail when cigarettes are purchased) categories, Federal Trade Commission data reveal that US tobacco firms now spend $85 \%$ of their promotional dollars via retailers. A similar scenario is evident in Canada. Based on data gleaned from internal industry documents, "retail POS" and "trade promotion" accounted for $53 \%$ of the Canadian tobacco industry's promotional budget in $1996 .{ }^{14}$ At the time, sponsorship was also permissible, generating $41 \%$ of promotional spending. Considering that a tobacco sponsorship ban has been implemented in Canada since October 2003, promotion at retail

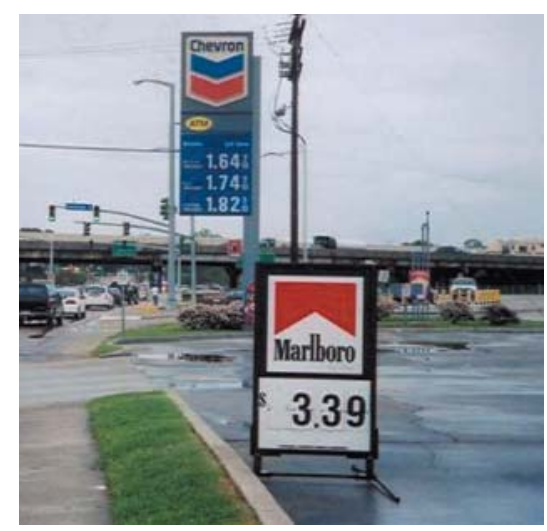

Figure 1 Marlboro signage, located next to a gas (petrol) station in Baton Rouge, Louisiana, USA, serves as a "mini-billboard". Camel "Pleasure to Burn" ads were also affixed to streetlights situated on gas station property. Photo taken on 29 March 2004 will presumably become even more prominent.

Tobacco promotion at retail is pervasive. The Point of Purchase Advertising Institute monitors in-store advertising expenditures for 22 industries, and reveals that the tobacco industry is the top spender on in-store media. ${ }^{15}$ Merchants receive significantly more money for tobacco display allowances relative to other product categories. Feighery and colleagues, for example, compared incentive programmes among small retail outlets in Santa Clara, California for five different product types: tobacco, beer and wine, soft drinks, snack foods, and candy. They found that, among the five measured product categories, approximately $78 \%$ of incentive payments came from tobacco firms. ${ }^{16}$

US tobacco firms typically provide incentives to retailers in exchange for their brands having at least $40 \%$ of shelf space (Philip Morris and RJ Reynolds (RJR) purportedly negotiate for as much as $55 \%$ ), obtaining desirable shelf placement, displaying promotional items and signage, meeting minimum sales volume standards, providing "buydowns" (retailers pass along reduced prices to consumers), and maintaining one of their brands as the cheapest available. ${ }^{13}{ }^{17-19}$ Some of these incentive programmes have undergone considerable scrutiny, being the subject of antitrust litigation initiated by competing tobacco firms. The Liggett Group filed an antitrust suit against RJR claiming that the firm's "Everyday Low Pricing" programme was unfair. In an attempt to minimise the competitiveness of contending deep discount brands, RJR's programme required that their brands, such as Best Value or Monarch, be the lowest priced offerings at retail. ${ }^{17}$ RJR, meanwhile, alleged that Philip Morris' "Retail Leaders" programme, implemented in 1999, was anti-competitive because the firm had considerable clout with its market share and was forcing retailers to give brands, such as Marlboro, superior shelf positions. ${ }^{17} 20$

\section{REPETITION}

Repetition is regarded as a cornerstone principle for successfully communicating brand identity. Repetition, both over time and across multiple media, promotes "friendly familiarity". A dense environment of cigarette promotion and imagery gives the impression that tobacco use is socially acceptable, desirable, and prevalent..$^{21}$ These impressions are further reinforced by the fact that cigarettes are so readily available. Because tobacco products may be acquired at a vast array of outlets, 
contradictory messages are communicated about the dangerousness of product use. In this issue of Tobacco Control, Henriksen and colleagues ${ }^{22}$ add to the literature about children and youth being exposed to cigarette promotions in POP environments. ${ }^{23}{ }^{24}$ In many cases, retailers with in-store tobacco promotions are located in close proximity to schools $^{25} 26$ and in-store promotions and cigarettes are often displayed at low eye levels adjacent to candy. ${ }^{27-29}$

In some jurisdictions, action has been taken to counter the promotional impact at retail. In Saskatchewan, provincial legislation took effect on 11 March 2002 and stipulates that both the promotion and display of tobacco and tobaccorelated products are prohibited in locations where people less than 18 years old have access. The Tobacco Control Act prompted cigarette "power walls" to be covered, and retailers used curtains, frosted glass, and closed cupboards to ensure that tobacco products were not publicly displayed (fig 2).* During May 2002, Rothmans, Benson and Hedges (RBH), Canada's second largest tobacco manufacturer, challenged the Act on constitutional grounds. The legislation was upheld by the Saskatchewan Court of Queen's Bench during September 2002, yet RBH was successful when appealing the decision. The Saskatchewan Court of Appeal declared the Act inoperative under the premise that Section 6 was inconsistent with Section 30 of federal legislation, the Tobacco Act. The Supreme Court of Canada has authorised Saskatchewan to appeal the most recent decision, and it is expected that the case will be heard during 2005. ${ }^{31}$ Saskatchewan, with a population of roughly one million, does not represent a large market for the Canadian tobacco industry. However, if Section 6 of Saskatchewan's Tobacco Control Act is upheld, similar stipulations are expected to be enforced in Manitoba, as well as Canada's most populous province, Ontario. It is also anticipated that the Supreme Court of Canada trial will help inform the implementation of retail display ban policies being proposed elsewhere (for example, South Africa, Ireland, and New South Wales, Australia). ${ }^{31}$

The retail venue is now the primary promotional medium for the tobacco industry. Left unregulated, tobacco merchandising in the retail environment will continue to proliferate. Policies such as Saskatchewan's Tobacco Control Act

\footnotetext{
* "Power walls" refer to the extensive rows of cigarette packages, in quantities that far exceed what is needed to meet short term purchase levels, which are commonly visible as a backdrop to the cash register. ${ }^{30}$
}
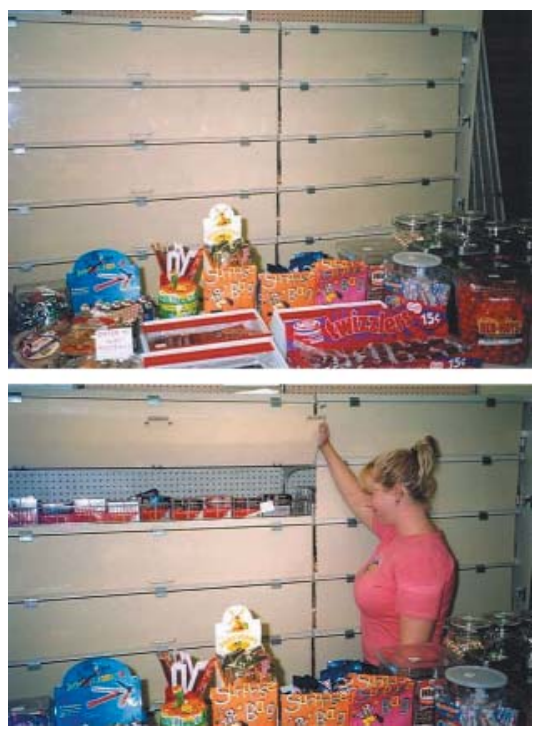

Figure 2 Out of sight, out of mind: Under Section 6 of Saskatchewan's Tobacco Control Act, cigarettes are no longer visible when purchasing the twizzlers or jawbreakers that are seen in the foreground. Photographs taken 5 October 2003.

seem warranted, but anything short of a full tobacco promotion ban (as stipulated by the Framework Convention on Tobacco Control) will merely prompt another shift in promotional spending. Alluding to the earlier quote about squeezing a balloon, it is now time to "pop" the balloon in the interest of public health.

Tobacco Control 2004;13:209-210. doi: $10.1136 /$ tc. 2004.009043

Correspondence to: Professor Timothy Dewhirst, Dept of Management \& Marketing, College of Commerce, University of Saskatchewan, 25 Campus Drive, Saskatoon, SK, S7N 5A7, Canada; dewhirst@commerce.usask.ca

Timothy Dewhirst is a Canada-US Fulbright Scholar, with the University of California, San Francisco hosting a six month research term

\section{REFERENCES}

1 Federal Trade Commission. Federal Trade Commission cigarette report for 2001. Washington DC: FTC, 2003.

2 Dewhirst T. Smoke and ashes: tobacco sponsorship of sports and regulatory issues in Canada. In: Kahle LR, Riley C, eds. Sports marketing and the psychology of marketing marketing and the psychology of marketing Associates, 2004:327-52.

3 Weir J. Tobacco advertising: the New Zealand experience. Tobacco Control 1995:4:90-1.

4 Fraser T. Phasing out of point-of-sale tobacco advertising in New Zealand. Tobacco Control 1998;7:82-4.

5 Harper T. Marketing life after advertising bans. Tobacco Control 2001;10:196-7.

6 Carter S. Worshipping at the Alpine altar: promoting tobacco in a world without advertising Tobacco Control $2001 ; 10: 391-3$

7 Wakefield M, Letcher T. My pack is cuter than your pack. Tobacco Control 2002;1 1:154-6.

8 Carter SM. New frontier, new power: the retail environment in Australia's dark market. Tobacco Control 2003;12(suppl III):iii95-101.
9 Sparks R, Dewhirst T, Jette $S$, et al. Historical hangovers or burning possibilities: regulation and adaptation in global tobacco and alcohol sponsorship. In: Amis J, Cornwell TB, eds. Global sport sponsorship: a multidisciplinary study. (in press).

10 Celebucki CC, Diskin K. A longitudinal study of externally visible cigarette advertising on retail storefronts in Massachusetts before and after the Master Settlement Agreement. Tobacco Control 2002; 11 (suppl II):ii47-53.

11 Wakefield MA, Terry-McElrath YM, Chaloupka FJ, et al. Tobacco industry marketing at point of purchase after the 1998 MSA billboard advertising ban. Am J Public Health 2002;92:937-40.

12 Herring HB. Signs of bygone days. The New York Times, 25 April 1999:Sec.4, 2.

13 Beirne M. Tobacco row: cigarette makers step up retail war. Brandweek 2002 December 2:3.

14 Pollay RW. Tobacco promotion spending patterns in Canada. Prepared for JTI-Macdonald Corp., Imperial Tobacco Canada Ltd., and Rothmans, Benson \& Hedges Inc. v. The Attorney General of Canada, Quebec Superior Court, Exhibit D239a, 2002

15 Gottesman A. Store wars. Adweek 1997 December 1:20.

16 Feighery EC, Ribisl KM, Achabal DD, et al. Retail trade incentives: how tobacco industry practices compare with those of other industries. Am J Public Health 1999:89:1564-6.

17 Beirne M. Big tobacco gets tough. Brandweek 14 May 2001:29-34.

18 Bloom PN. Role of slotting fees and trade promotions in shaping how tobacco is marketed in retail stores. Tobacco Control $2001 ; 10: 340-4$

19 Feighery EC, Ribisl KM, Clark Pl, et al. How tobacco companies ensure prime placement of their advertising and products in stores: interviews with retailers about tobacco company incentive programs. Tobacco Control 2003;12:184-8.

20 Balto $D$. Recent legal and regulatory developments in slotting allowances and category management. Journal of Public Policy and Marketing 2002;21:289-94.

21 Pollay RW. How cigarette advertising works: rich imagery and poor information. Expert report prepared for JTI-Macdonald Corp. Imperial Tobacco Canada Ltd., and Rothmans, Benson \& Hedges Inc. v. The Attorney General of Canada. Quebec Superior Court, Exhibit D-57, 2002.

22 Henriksen L, Feighery EC, Schleicher NC, et al. Reaching youth at the point of sale: cigarette marketing is more prevalent in stores where adolescents shop frequently. Tobacco Control 2004;13:315-8.

23 Schooler C, Feighery EC, Flora JA. Seventh graders' self-reported exposure to cigarette marketing and its relationship to their smoking behavior. Am J Public Health 1996;86:1216-21

24 Donovan RJ, Jancey J, Jones S. Tobacco point of sale advertising increases positive brand user imagery. Tobacco Control 2002;11:191-4.

25 Anon. Retail promotions on the rise. Filter tips: a review of cigarette marketing in Canada, 2nd ed. Physicians for a Smoke-Free Canada, 1999. http://www.smoke-free.ca/filtertips02/ Retail.htm.

26 Slater S, Chaloupka FJ, Wakefield M. State variation in retail promotions and advertising for Marlboro cigarettes. Tobacco Control 2001;10:337-9.

27 Cummings KM, Sciandra R, Lawrence J. Tobacco advertising in retail stores. Public Health Reports 1991;106:570-5.

28 Feighery EC, Ribisl KM, Schleicher NC, et al. Cigarette advertising and promotional strategies in retail outlets: results of a statewide survey in California. Tobacco Control 2001;10:184-8.

29 Terry-McElrath Y, Wakefield M, Giovino G, et al. Point-of-purchase tobacco environments and variation by store type - United States, 1999 MMWR Morb Mortal Wkly Rep 2002;51:184-7.

30 Greaves L. Canada: demolishing the power walls. Tobacco Control 2003;12:7-8.

31 Cunningham R. Banning retail displays and signage. Toronto, Canada: Ontario Tobacco Control Conference, 6 May 2004. 